\title{
Scientific collaboration and high-technology exchanges among BRICS and G-7 countries
}

\author{
Hamid Bouabid $^{1}$, Adèle Paul-Hus ${ }^{2}$ and Vincent Larivière ${ }^{2}$ \\ ${ }^{1}$ Faculty of Science, Mohammed V University, 4, Avenue Ibn Battouta B.P. 1014 RP, Rabat Morocco. \\ Email: $\underline{\text { h.bouabid@fsr.ac.ma }}$ \\ ${ }^{2}$ École de bibliothéconomie et des sciences de l'information, Université de Montréal, C.P. 6128, Succ. \\ Centre-Ville, Montréal, QC. H3C 3J7 (Canada) and \\ Observatoire des Sciences et des Technologies (OST), Centre Interuniversitaire de Recherche sur la \\ Science et la Technologie (CIRST), Université du Québec à Montréal, CP 8888, Succ. Centre-Ville, \\ Montréal, QC. H3C 3P8 (Canada) \\ Email: adele.paul-hus@umontreal.ca; vincent.lariviere@umontreal.ca
}

\begin{abstract}
Over the last two decades, emerging countries located outside North America and Europe have reshaped the global economy. These countries are also increasing their share of the world's scientific output. This paper analyzes the evolution of BRICS (Brazil, Russia, India, China and South Africa) and G-7 countries' international scientific collaboration, and compares it with high-technology economic exchanges between 1995-1997 and 2010-2012. Our results show that BRICS scientific activities are enhanced by their high-technology exports and, to a larger extent, by their international collaboration with G-7 countries which remains, over the period studied, at the core of the BRICS scientific collaboration network. However, while high-technology exports made by most BRICS countries to G-7 countries have increased over the studied period, both the intra-BRICS hightechnology flows and the intra-BRICS scientific collaboration have remained very weak.
\end{abstract}

\section{Key words}

G-7, BRICS, scientific collaboration, high-technology, economic cooperation

\section{Introduction}

Over the last two decades, emerging countries located outside North America and Europe have shown high economic growth rates. Many analysts thus predict that the world's economic center of gravity will shift from Western countries, namely G-7 countries (Canada, France, Germany, Italy, Japan, UK and USA), to emerging countries such as those from Southeast Asia and Latin America (Klein, 2009; Grether, 2010; Kharas, 2010; OECD, 2010; Quah, 2011; Klein and Salvatore, 2013). These economic transformations might be associated with a similar shift of the science and technology center of gravity, and scientific collaboration might play an important role in such changes. The BRIC Association, formed originally by Brazil, Russia, India and China, became official in 2009, with the 
aim of improving its global economic situation by co-operation among the four countries (BBC, 2009). In 2011, South Africa joined the association, which then became known as BRICS (South Africa, 2011). The G-7 countries are the seven wealthiest developed nations and have the largest research and development activities worldwide (King, 2004).

This paper first compares the evolution of scientific production of G-7 and BRICS countries between 1995-1997 and 2010-2012 for the fields of Engineering and Technology, Medical Sciences and Earth and Space. The scientific collaboration between BRICS and G-7 countries and its evolution over the period 1995-1997 to 2010-2012 is then analyzed for each major field. Specifically, this paper investigates how this evolution is being influenced by endogenous collaboration (amongst BRICS) and by exogenous collaboration (with G-7 countries). Finally, economic collaboration is explored as a potential factor explaining scientific collaboration using data on high-technology economic exchanges.

\section{Background}

\section{Economic and Scientific Growth}

BRICS countries have shown very high economic growth rates in recent years. In 2014, BRICS economies generated more than $20 \%$ of the world's Gross Domestic Product (GDP) (UNCTAD Statistics, 2015a), coupled with a significant annual growth rate: 10.0\% for China, $7.3 \%$ for India, 3.6\% for Brazil, 2.8\% for Russia and 2.6\% for South Africa (UNCTAD Statistics, 2015b) during the period 2005-2014, while the world's average annual growth rate was at $2.5 \%$. The BRICS growth in GDP was also accompanied by an increase in their exports. Hanson (2012) noticed a high growth of exports for emerging countries between 1992 and 2008, with an average annual exports growth of $18 \%$ in China and $14 \%$ in India. Furthermore, the share of global exports coming from 15 middleincome countries ${ }^{1}$ (in terms of market size) more than doubled during this period, increasing from $21 \%$ to $43 \%$.

Research and development (R\&D) is also often linked with economic growth: it typically stimulates R\&D spending, and in return R\&D spending stimulates economic growth. According to OECD Science, Technology and Industry Outlook (2012), China leads the group of emerging economies, as its share in global R\&D spending increased from $7 \%$ in 2004 to $10 \%$ in 2008, and then to $13 \%$ in 2009. OECD data also show that while R\&D spending declined in most countries as a result of the economic crisis, Brazil, South Korea, Malaysia, Mexico, Singapore and Argentina continued to increase their spending. Moreover, China, South Korea and other emerging Asian economies are outinnovating the Western world (OECD, 2012).

\footnotetext{
${ }^{1}$ These countries are: Brazil, South Korea, Mexico, Russia, Argentina, Turkey, Indonesia, Poland, South Africa, Thailand, Egypt, Colombia, Malaysia, Philippines, and Chile.
} 
As shown by Leydesdorff and Zhou (2005), these investments lead to a growth in scientific outputs: China, South Korea, Singapore, India, South Africa, Russia and Iran increased significantly their scientific activities. These emerging nations not only increased their share of the world's scientific production but their national science systems also experienced an endogenous growth. The authors thus predict that the center of gravity of the science world will change accordingly. Table 1 confirms these trends, showing that for BRICS countries, single country papers are typically growing as much as papers with foreign colleagues. We could also add that the scientific impact of BRICS papers is likely to increase, as it has been shown that their papers' citation half-lives are increasing at faster rate than that of developed countries' papers (Bouabid and Larivière, 2013).

Table 1. Increase in terms of number of publications for G-7 and BRICS countries, 1995-1997 vs. $2010-2012^{2}$

\begin{tabular}{|c|c|c|c|c|c|c|c|c|c|}
\hline \multirow[b]{2}{*}{ Country } & \multirow[b]{2}{*}{$\begin{array}{c}\text { Total } \\
\text { papers }\end{array}$} & \multirow{2}{*}{$\begin{array}{l}1995-1997 \\
\text { International } \\
\text { co-authored } \\
\text { papers }\end{array}$} & \multirow[b]{2}{*}{$\begin{array}{l}\text { Single } \\
\text { country } \\
\text { papers }\end{array}$} & \multirow[b]{2}{*}{$\begin{array}{c}\text { Total } \\
\text { papers }\end{array}$} & \multirow{2}{*}{$\begin{array}{l}2010-2012 \\
\text { International } \\
\text { co-authored } \\
\text { papers }\end{array}$} & \multirow[b]{2}{*}{$\begin{array}{l}\text { Single } \\
\text { country } \\
\text { papers }\end{array}$} & \multicolumn{3}{|c|}{ Increase rate $(10-12 / 95-97)$} \\
\hline & & & & & & & Total papers & $\begin{array}{l}\text { International } \\
\text { co-authored } \\
\text { papers }\end{array}$ & $\begin{array}{l}\text { Single } \\
\text { country } \\
\text { papers }\end{array}$ \\
\hline Canada & 104,146 & 29,957 & 74,189 & 177,019 & 83,730 & 93,289 & $70 \%$ & $180 \%$ & $26 \%$ \\
\hline France & 135,200 & 43,145 & 92,055 & 202,597 & 106,682 & 95,915 & $50 \%$ & $147 \%$ & $4 \%$ \\
\hline Germany & 177,817 & 54,098 & 123,719 & 287,418 & 145,065 & 142,353 & $62 \%$ & $168 \%$ & $15 \%$ \\
\hline Italy & 83,342 & 26,326 & 57,016 & 167,251 & 75,102 & 92,149 & $101 \%$ & $185 \%$ & $62 \%$ \\
\hline Japan & 189,908 & 26,905 & 163,003 & 231,426 & 63,330 & 168,096 & $22 \%$ & $135 \%$ & $3 \%$ \\
\hline UK & 199,982 & 52,689 & 147,293 & 302,631 & 152,779 & 149,852 & $51 \%$ & $190 \%$ & $2 \%$ \\
\hline USA & 781,578 & 128,136 & 653,442 & $1,093,722$ & 350,461 & 743,261 & $40 \%$ & $174 \%$ & $14 \%$ \\
\hline G-7 & $1,671,973$ & 361,256 & $1,310,717$ & $2,462,064$ & 977,149 & $1,484,915$ & $47 \%$ & $170 \%$ & $13 \%$ \\
\hline Brazil & 19,932 & 7,003 & 12,929 & 107,547 & 28,565 & 78,982 & $440 \%$ & $308 \%$ & $511 \%$ \\
\hline China & 44,401 & 10,505 & 33,896 & 490,606 & 119,467 & 371,139 & $1005 \%$ & $1037 \%$ & $995 \%$ \\
\hline India & 47,109 & 5,720 & 41,389 & 139,005 & 29,950 & 109,055 & $195 \%$ & $424 \%$ & $163 \%$ \\
\hline Russia & 82,627 & 19,514 & 63,113 & 85,232 & 27,253 & 57,979 & $3 \%$ & $40 \%$ & $-8 \%$ \\
\hline S. Africa & 10,817 & 2,732 & 80,85 & 27,812 & 13,891 & 13,921 & $157 \%$ & $408 \%$ & $72 \%$ \\
\hline BRICS & 204,886 & 45,474 & 159,412 & 850,202 & 219,126 & 631,076 & $315 \%$ & $382 \%$ & $296 \%$ \\
\hline
\end{tabular}

On the technological dimension, a report by BCG (2013) stated that for the 2006-2013 period, the number of patents granted by the United States Patent and Trademark Office (USPTO) to companies based in Rapid Developing Economies (RDEs) increased at a rate more than three times higher than that of companies from other countries. The BCG even predicted that if this growth continued, $25 \%$ of patents issued by the USPTO in 2018 would belong to RDEs.

These data suggest that emerging countries are aiming to build up their national research systems to international quality standards. However, the disciplines in which these countries are active vary greatly. Harzing and Giroud (2014) applied the concept of Revealed Comparative Advantage (RCA)

\footnotetext{
${ }^{2}$ The total for G7 and BRICS countries includes double counts due to collaboration within G7 or within BRICS. Hence, such numbers have to be considered as country-paper combinations rather than distinct numbers of papers.
} 
to scientific output to highlight where countries have a scientific advantage (in terms of their areas of specialization). They showed that different countries exhibit very different research profiles: USA, UK, Canada, the Netherlands and Israel have their main RCA in the Social Sciences while China, Singapore, Taiwan and South Korea have a very strong RCA in Engineering and Technology with comparative disadvantages in all other disciplines with the exception of Physical Sciences. India is characterized by a modest RCA in Physical Sciences but demonstrated a rather strong comparative disadvantage in the Social Sciences. Russia also has a strong RCA in Physical Sciences. South Africa has a RCA in Social Sciences and Environmental Sciences.

Yang, Yue, Ding and Han (2012) found that there is a certain relationship between countries' areas of specialization and their level of science and technology (S\&T) activities. While the disciplinary structure of all G-7 countries is similar to that of other high S\&T countries, BRICS countries' research systems share fewer common characteristics. The authors also showed that, from 1991 to 2009, the disciplinary structure of BRICS countries has evolved from being quite unbalanced-with the focus on only a few disciplines- to a much more balanced blend of disciplines similar to what is seen in G-7 countries. They concluded that, for BRICS countries, the reconfiguration of the disciplinary structure moves in parallel with a strong development of S\&T activities. However, this study did not address the question of science collaboration between BRICS and G-7 countries and if collaboration plays any role in developing their domestic scientific output in terms of disciplinary structure.

The increase of emerging countries' scientific output is to some extent driven by human resources mobility and international collaboration. Mobility refers to the training of BRICS' highly qualified scientists in developed countries, mainly in the USA, Japan, Canada and Western Europe. According to the Institute of International Education (2013), for the 2012-2013 period the USA hosted more than 34,000 Chinese scholars, 11,000 Indians, 3,200 Brazilians and 1,100 Russians. The return of these researchers to their homelands constitutes a strong transfer of science and technology to their respective countries, in addition to the fact that they typically maintain collaborative ties with their host institutions.

A second driver for BRICS' scientific productivity is the international collaboration between researchers from BRICS countries and their peers worldwide. Indeed, many authors have shown a positive relation between research productivity and scientific collaboration. Lee and Bozeman (2005), He, Geng and Campbell-Hunt (2009), Abramo, D’Angelo and Solazzi (2011) and Finlay, Ni and Sugimoto (2012) have all shown that collaboration is related with research output and scientific impact. Similarly, Defazio, Lockett and Wright (2009) found that while funding increased researcher productivity by approximately $14 \%$, collaboration increased it by almost $70 \%$. The positive effect of 
collaboration on the scientific impact of papers has also been shown using citations analysis (Beaver, 2004; Katz and Hicks, 1997; Larivière, Gingras, Sugimoto and Tsou, 2015; Levitt and Thelwall, 2010; Rigby, 2009). Finally, Sun, Kaur, Milojević, Flammini and Menczer (2013) found that scientific disciplines emerge from the splitting and merging of social communities in a collaboration network, which supports the theory that scientific collaboration shapes the dynamics of science.

\section{Data and Methods}

Data are drawn from Thomson Reuters' Web of Science database (WoS). Three scientific fields, based on the NSF field and subfield classification, were considered in the present analysis: Engineering and Technology, Medical Sciences (which includes Biomedical Research, Clinical Medicine and Health) and Earth and Space. Two periods are considered, 1995-1997 and 2010-2012. The first period was fixed before the creation of the BRICS alliance and the second one a decade and a half after, to measure the effect, if any, of this alliance on the scientific collaboration between these countries. Scientific collaboration between two countries is measured by the number of co-authored papers from these two countries and full counting is used. Before mapping scientific collaborations, matrixes are normalized using Jaccard Index (1901) as done by Hamers et al. (1989), Klavans and Boyack (2006) and Leydesdorff (2008).

Consider the matrix $[X]=X_{i j}$ where $1 \leq i, j \leq n$ represents the gross matrix of the number of coauthored papers between the countries $\mathrm{i}$ and $\mathrm{j}$. The normalized matrix $[J]=J_{i j}$ using the Jaccard index is written as:

$$
J_{i j}=\frac{X_{i j}}{X_{i m}+X_{m j}-X_{i j}}
$$

where

$$
X_{i m}=\sum_{j=1}^{n} X_{i j} \text { and } X_{m j}=\sum_{i=1}^{n} X_{i j}
$$

The last step in mapping is generating the science maps which can be done using one of the available and specifically conceived tools for science mapping. All the maps presented in this paper are produced using Gephi software after normalizing the collaboration matrix with Jaccard index as presented above. The respective scientific size of each country in a given field is the number of papers published by this country in this field. 


\section{Results and Discussion}

\section{Evolution of Countries' Scientific Production}

Table 2 presents the number of papers produced by G-7 and BRICS countries between 1995-1997 and 2010-2012 in major scientific fields. Unsurprisingly, the USA is still at the center of the world's scientific production. No significant change has occurred from the 1995-1997 to 2010-2012, except in the field of Engineering and Technology, where it has lost its leading position to China. Moreover, China significantly increased its scientific production in all considered fields between 1995-1997 and 2010-2012. Unsurprisingly, Russia has, by far, the lowest growth rate among the BRICS countries in all scientific fields, as it is still recovering from the fall of the USSR. Let us recall that for most of the second half of the $20^{\text {th }}$ century, the USSR was the second most active scientific superpower, surpassed only by the USA (Graham, 1993).

Table 2. Number of papers of G-7 and BRICS countries, by scientific area,

1995-1997 and 2010-2012

\begin{tabular}{|c|c|c|c|c|c|c|c|c|c|}
\hline \multirow[t]{2}{*}{ Country } & \multicolumn{3}{|c|}{ Engineering and Technology } & \multicolumn{3}{|c|}{ Medical Sciences } & \multicolumn{3}{|c|}{ Earth and Space } \\
\hline & $95-97$ & $10-12$ & $\begin{array}{l}\text { Increase } \\
\text { rate (\%) }\end{array}$ & $95-97$ & $10-12$ & $\begin{array}{r}\text { Increase rate } \\
(\%)\end{array}$ & $95-97$ & $10-12$ & $\begin{array}{l}\text { Increase } \\
\text { rate (\%) }\end{array}$ \\
\hline Canada & 10,981 & 20,382 & $86 \%$ & 42,912 & 78,233 & $82 \%$ & 7,668 & 13,459 & $76 \%$ \\
\hline France & 11,456 & 24,350 & $113 \%$ & 58,561 & 77,106 & $32 \%$ & 8,173 & 17,678 & $116 \%$ \\
\hline Germany & 17,022 & 28,138 & $65 \%$ & 74,815 & 121,577 & $63 \%$ & 8,889 & 21,956 & $147 \%$ \\
\hline Japan & 25,884 & 30,351 & $17 \%$ & 81,670 & 99,666 & $22 \%$ & 4,629 & 11,198 & $142 \%$ \\
\hline UK & 18,908 & 26,489 & $40 \%$ & 94,534 & 136,463 & $44 \%$ & 11,127 & 21,858 & $96 \%$ \\
\hline USA & 71,934 & 96,748 & $34 \%$ & 372,557 & 530,395 & $42 \%$ & 40,943 & 65,488 & $60 \%$ \\
\hline G-7 & 163,598 & 244,920 & $50 \%$ & 765,248 & 1120,537 & $46 \%$ & 85,896 & 164,981 & $92 \%$ \\
\hline Brazil & 1,438 & 8,121 & $465 \%$ & 7,692 & 51,195 & $566 \%$ & 1,052 & 4,138 & $293 \%$ \\
\hline Russia & 9,314 & 9,878 & $6 \%$ & 15,260 & 12,163 & $-20 \%$ & 5,458 & 8,981 & $65 \%$ \\
\hline India & 7,758 & 24,073 & $210 \%$ & 12,256 & 43,472 & $255 \%$ & 2,801 & 8,893 & $217 \%$ \\
\hline China & 7,877 & 105,160 & $1235 \%$ & 7,185 & 128,427 & $1687 \%$ & 1,735 & 28,544 & $1545 \%$ \\
\hline S. Africa & 818 & 2,166 & $165 \%$ & 3,888 & 9,257 & $138 \%$ & 1,065 & 2,254 & $112 \%$ \\
\hline BRICS & 27,205 & 149,398 & $449 \%$ & 46,281 & 244,514 & $428 \%$ & 12,111 & 52,810 & $336 \%$ \\
\hline
\end{tabular}

\section{Evolution of Scientific Collaboration}

China's scientific collaboration with G-7 countries grew substantially between 1995-1997 and 20102012 (Figures 1, 2 and 3 and Appendix 1 for the raw matrixes of collaboration). Figure 1 shows that China's scientific output exceeded that of the USA in Engineering and Technology in 2010-2012. In this field, India and Brazil have also increased their scientific output and intensified their collaboration with almost all G-7 countries. Two major factors may contribute to this growth as well as the typical pattern of scientific development it follows (Basalla, 1967): tertiary students' mobility and high technology activities of BRICS countries. Indeed, the OECD report (2013) on international student

\footnotetext{
${ }^{3}$ The total for G7 and BRICS countries includes double counts due to collaboration within G7 or within BRICS. Hence, such numbers have to be considered as country-paper combinations rather than distinct numbers of papers.
} 
mobility stated that the largest numbers of international students in 2011 were from China $(723,000)$, India $(223,000)$, Korea $(139,000)$ and Russia $(71,000)$, and that Brazil topped the countries of Central and South America. These students play a key role in the intensification of research collaboration when back in their country of origin, maintaining research ties with colleagues from host countries. This report also shows that five of the six most attractive countries for foreign tertiary students are G-7 countries: USA, UK, Germany, France and Canada. Regarding the second major factor, hightechnology exports of BRICS economies to G-7 economies have significantly increased (UNCTAD Statistics, 2014), which might be both a cause and a consequence of more research activities in these domains. For example, 'Electronics (excluding parts and components), SITC $751+752+761+762$ $+763)^{\prime}$ exports from BRICS ${ }^{4}$ to G-7 economies have grown approximately 624\% from 1995 to 2012 , reaching 123.6 billon US\$ in 2012 (despite a decrease in Brazil's exports and South Africa's small increase of 4.2\%). Similarly, BRICS exports of 'Machinery and transport equipment, SITC 7' also grew 542\% during the same period, reaching more than 423 billion US\$ in 2012.

\footnotetext{
${ }^{4}$ Statistic for China refers to China PR, Hong Kong, Macao and Taiwan.
} 


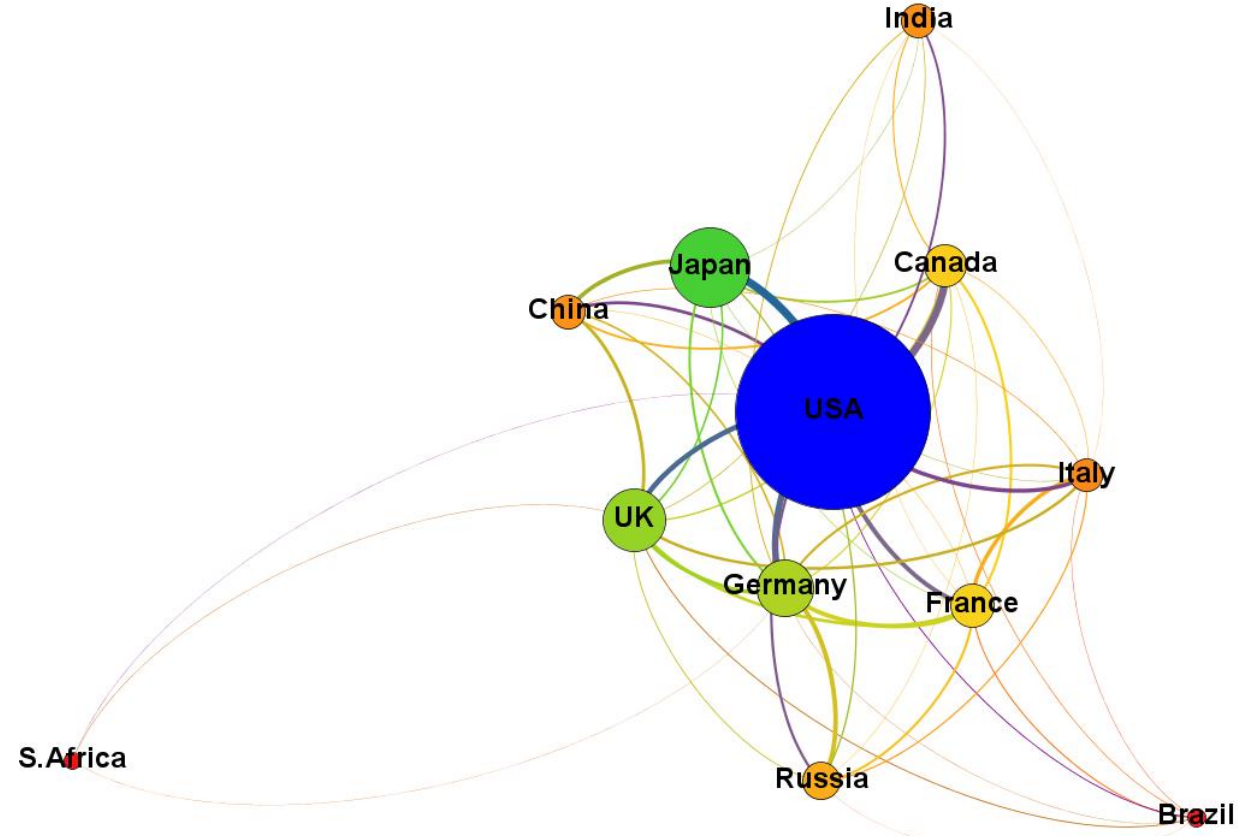

a) Period 1995-1997

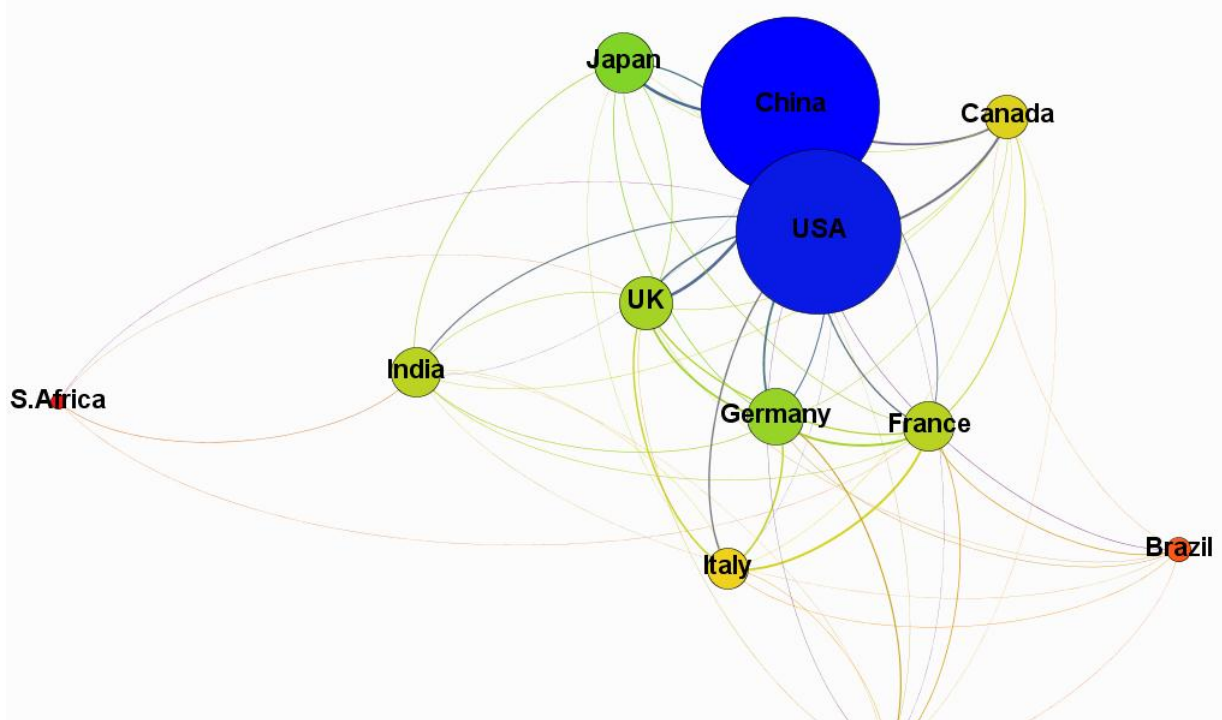

Russia

Figure 1. Scientific collaboration of G-7 and BRICS countries in the field of Engineering and Technology

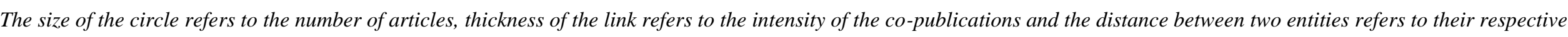
proximity in the cluster 
Figure 2 provides the collaboration network of BRICS and G-7 countries in Medical Sciences. In fact, Medical Sciences is the only field where no noticeable change can be observed in BRICS and G-7 collaboration patterns, except for China, which is now much closer to the G-7 cluster. The G-7 group has remained the core of the network with intensive scientific collaboration among its constituents. Brazil, Russia, India and South Africa remain at the cluster's periphery even if their scientific production has significantly increased between the two periods. While no increase has occurred in the BRICS intra-closeness and intra-collaboration, the growth rate of the Medical Sciences output for each BRICS country is largely exceeding the rate observed for G-7 countries (Table 2). As health appeared to be an important issue at the 3rd BRICS Summit in 2011 (Harmer and Fleck, 2014), intensification of BRICS' Medical Sciences production and intra-BRICS collaboration could be expected. Since 2011, BRICS has held annual meetings discussing specific health issues, which have been found to be different than those of the Organization of Economic Co-operation and Development (OECD) countries (Hamer and Fleck, 2014). 


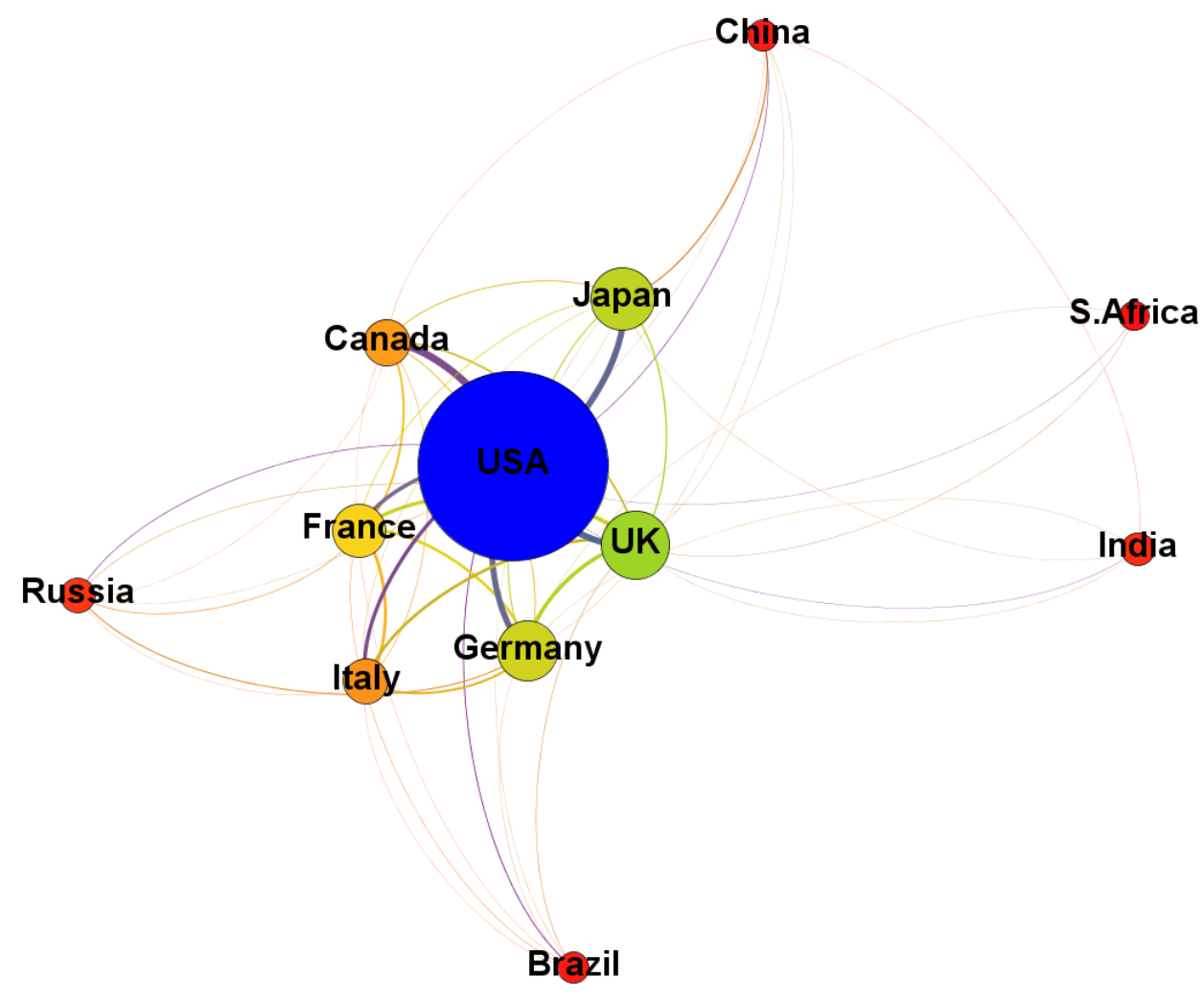

a) Period 1995-1997

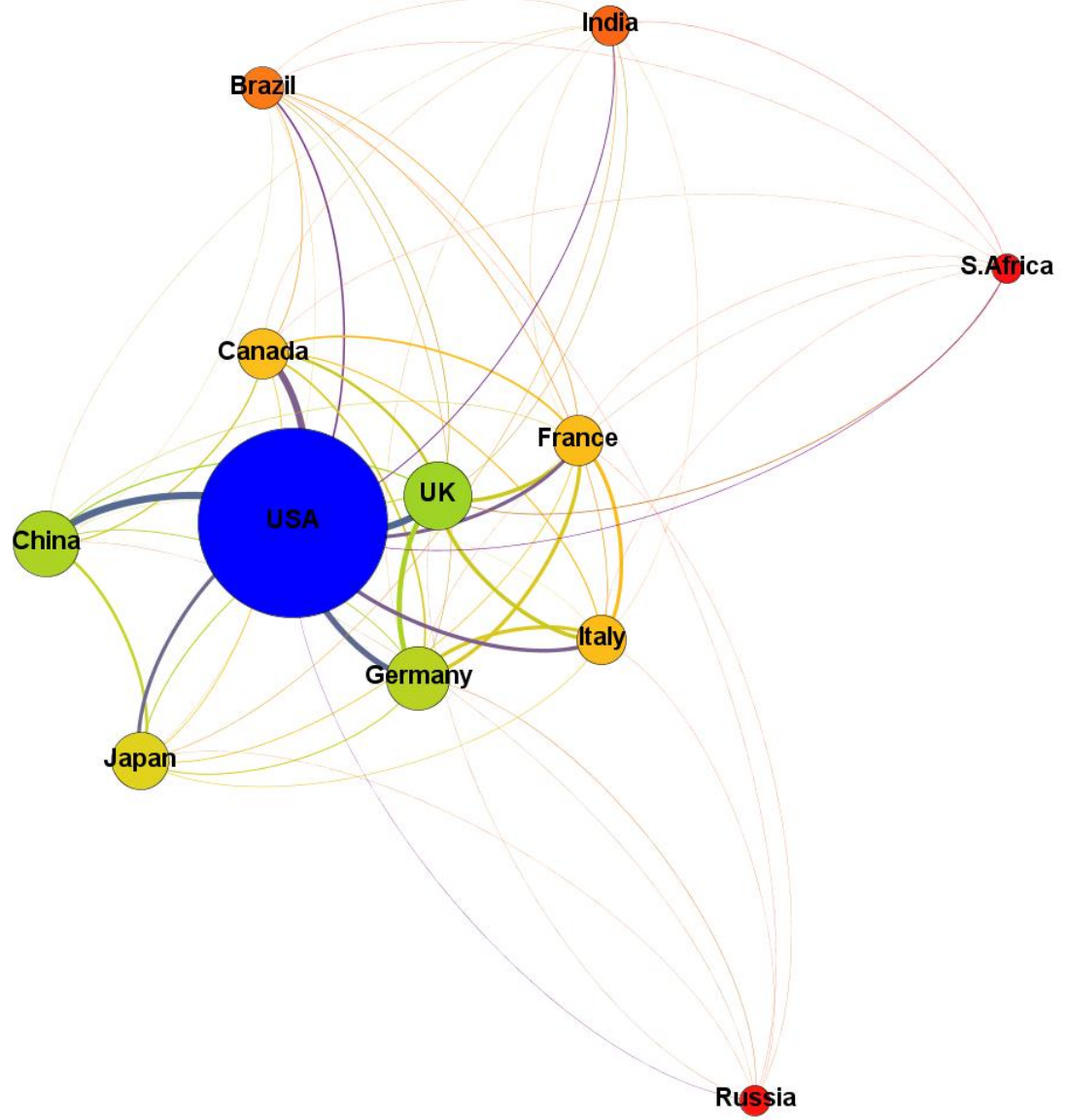

b) Period 2010-2012

Figure 2. Scientific collaboration of G-7 and BRICS countries in the field of Medical Sciences

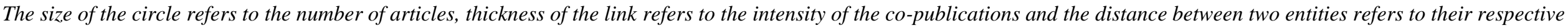
proximity in the cluster 
Earth and Space is the second field in which China demonstrates a strong progression, with a research output that is greater than that of all other G-7 countries except the USA (Appendix 1 for the raw matrix). In 2013, China successfully landed the unmanned Chang'e-3 spacecraft on the moon, becoming the first country to carry out a lunar touchdown in almost four decades, and the third country in the world - after the USA and Russia - to reach Earth's satellite. China's first self-built rocket was launched in 1990 carrying a satellite into orbit (Lakdawalla, 2014) and in 2003, China's first astronaut was successfully sent into Earth's orbit (Liao, 2005). These clear advances in Earth and Space can also be related to the growing Chinese scientific production and intensifying collaboration with G-7 countries in Engineering and Technology (Figure 1).

Along these lines, India's first astronaut flew in 1984 as part of the Soviet Soyuz mission. In 2008, India successfully launched its first rocket into moon orbit, the Chandrayaan-1, in search of water evidence (Goswami and Annadurai, 2009). Despite that space experience, India does not show the same level of collaboration with G-7 countries in Earth and Space (Figure 3). Moreover, India's progress in the field of Engineering and Technology, both in terms of production and collaboration, is relatively less important than that of China (Figure 1).

As South Africa was the last country to join the BRIC alliance in 2011, it seems that its "scientific integration" is still to come. Indeed, as shown in Figures 1 to 3, it is the farthest from either the G-7 or other BRICS countries in all scientific fields studied. Even if the number of papers produced by South Africa has substantially increased between 1995-1997 and 2010-2012 (Table 2), the country is still at the periphery of the BRICS cluster, and far away from the G-7 cluster. Its main partners are the UK and USA, which suggests that its scientific output growth (408\%, see Table 2) is rather exogenous than endogenous, and due to international collaborations.

Figures 1 to 3 show that the scientific collaboration amongst BRICS countries did not grow as fast as that between BRICS and G-7. In contrast to G-7 countries, where proximity in terms of scientific collaboration has proven to be enduring, the increase of BRICS' scientific production, when observed, seems to be more individual and endogenous than resulting from any alliance or collective enterprise. According to Chan and Daim (2012), when exploring the role of technology foresight activities with regards to innovation in BRICS countries, one has to consider differences in their aspirations concerning their future role in the global economy, political will, availability of economic resources, technological positions, and social conditions, which may help explain the more competitive than collaborative nature of the scientific relationship between China and India. "Cooperation in S\&T" was one of the five priorities of the G-7 as early as 1985 and may explain the dense scientific cluster of G7 countries seen in Figures 1 to 3 and the difference between the G-7 group and the BRICS group. Indeed, BRICS are a quite heterogeneous group, while all G-7 countries except Japan are of European 
heritage, with historical ties related to language and culture. Such ties do not exist between Russia and Brazil or China and India. Moreover, four of the G-7 countries - Germany, France, Italy and UK-are members of the European Union, which has fostered, through structured science and technology research programs, scientific cooperation over the last few decades. Such programs of scientific cooperation do not yet exist at the level of BRICS countries despite an explicit resolution made during

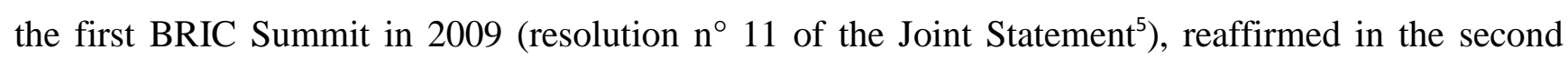

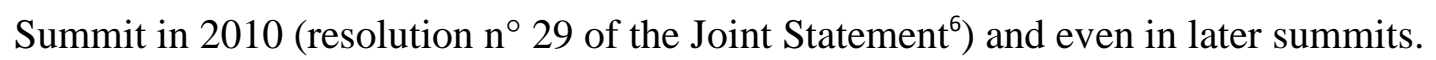

On the whole, these results suggest that the BRICS alliance is much more based on political and economic relations than scientific ones. The scientific intra-collaboration intensity (links) and proximity (distances) between these countries are weak and do not seem to evolve in a positive direction. This seems to confirm the results of Finardi (2015), who showed that some relatively strong collaboration ties exist but these intra-ties were not necessarily the strongest the countries experienced. Geographical distance may explain in part these weak collaboration links (Acosta, Coronado, Ferrándiz and León, 2011; Hoekman, Frenken and Tijssen 2010; Scherngell and Yuanjia, 2011). Indeed, the mean geographical distance of the BRICS group is 9,383 km (with a standard deviation of $4,867 \mathrm{~km}$ ) which is almost twice the mean distance of the G-7 group: 5,708 km (with a standard deviation of $3,503 \mathrm{~km}$ ).

\footnotetext{
${ }^{5}$ Resolution $\mathrm{n}^{\circ} 11$ (2009 Summit): We reaffirm to advance cooperation among our countries in science and education with the aim, inter alia, to engage in fundamental research and development of advanced technologies.

${ }^{6}$ Resolution $n^{\circ} 29$ (2010 Summit): We reaffirm our commitment to advance cooperation among BRIC countries in science, culture and sports.

Source: BRICS Information Center, University of Toronto (www.brics.utoronto.ca).
} 


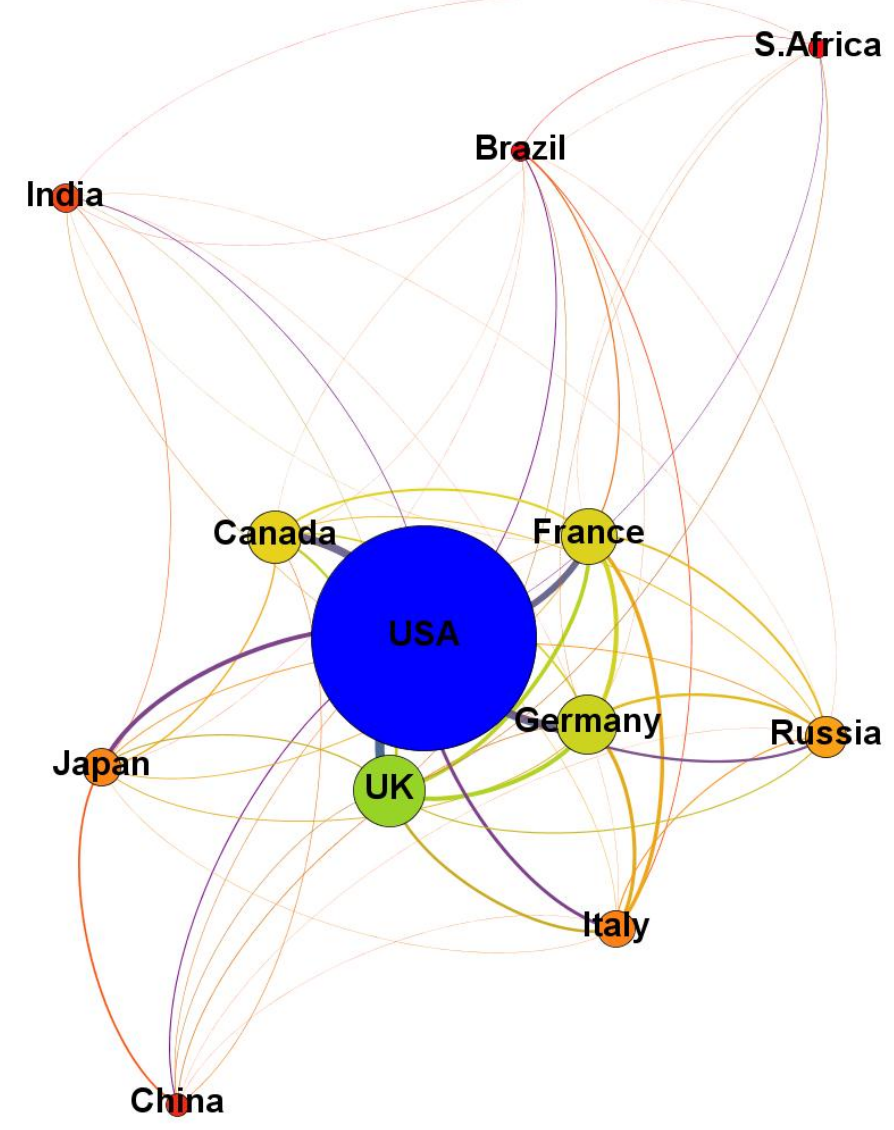

a) Period 1995-1997

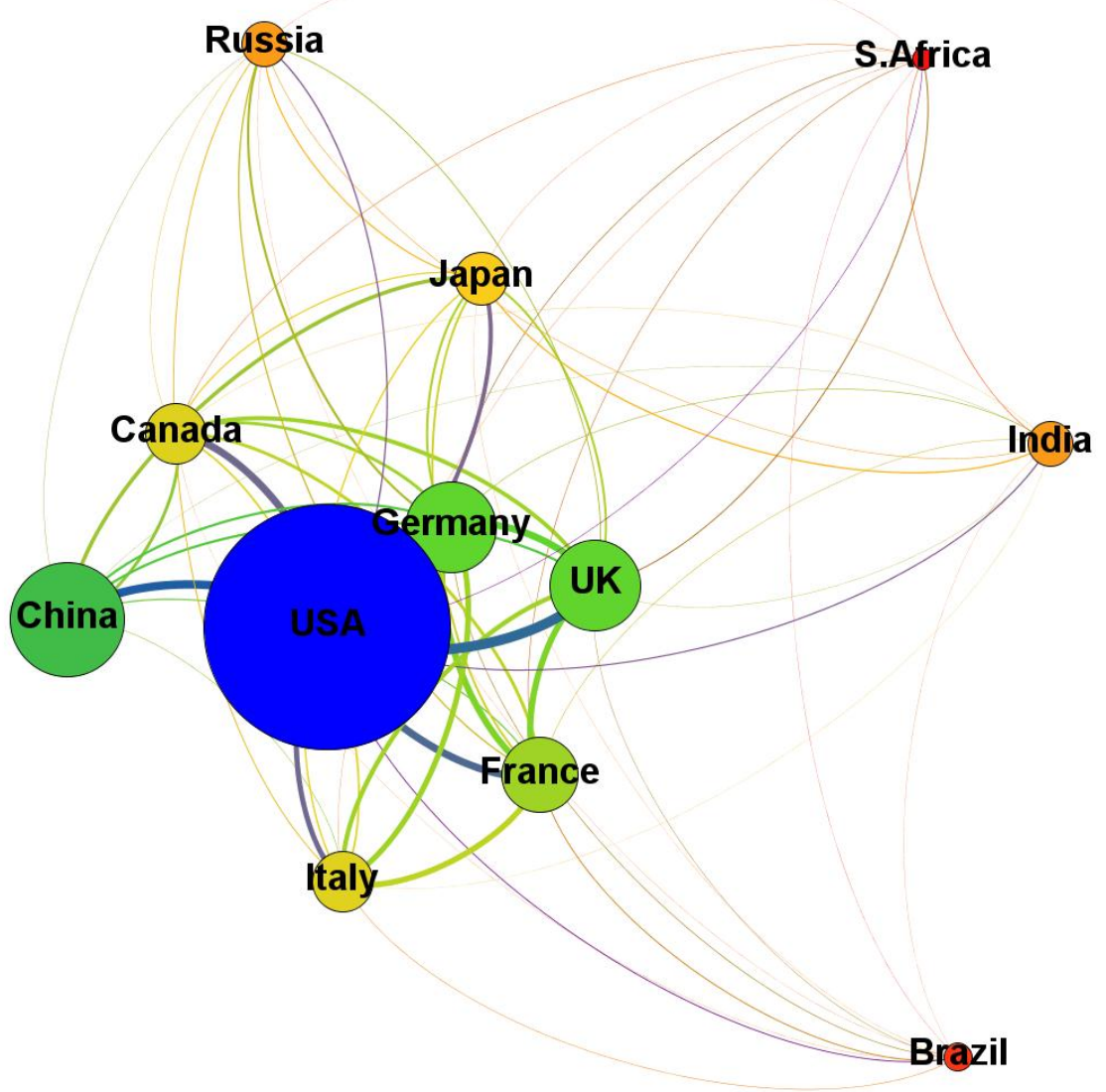

b) Period 2010-2012

Figure 3. Scientific collaboration of G-7 and BRICS countries in the field of Earth and Space

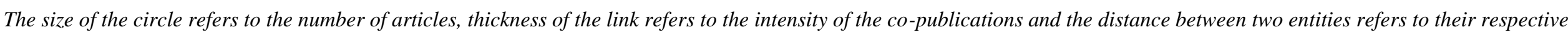
proximity in the cluster 


\section{Scientific Collaboration and High-technology Exchanges}

In order to obtain a broader understanding of the scientific collaboration between countries, numerous factors have to be taken into account. Harzing and Giroud (2014) recently proposed a model detailing factors that may explain research profile and scientific competitiveness of a country. These factors include the Demand conditions (e.g. academic population, public and private sectors); the Factor conditions (e.g. human resources, physical resources, knowledge resources and capital resources); the Strategy, structure and rivalry (e.g. university goals and strategy, competition); the Related and supporting industries (e.g. non-higher education research institutions and the IT industry); the Government (e.g. education and $\mathrm{R} \& \mathrm{D}$ funding policy) and a part of Chance whose effect cannot be easily predicted. Others have found a positive correlation between economic development and scientific collaboration, within Europe (Acosta et al., 2011) and within China (Scherngell and Yuanjia, 2011). However, the relationship between scientific cooperation and high-technology economic exchanges has never been explored, despite the commonly made assumption that we globally are in a knowledge and technology-based economy.

We explore here the relation between scientific collaboration and high-technology exports between BRICS and G-7 countries. As shown in Figure 4, high-technology exports ${ }^{7}$ of most BRICS countries have increased, especially exports made to G-7 countries (except for Brazil) from the 1995-1997 period to 2010-2012. The proximity (closeness) of BRICS countries, led by China, also increased though along different paths. The economic competitiveness of BRICS countries among themselves is made visible by the very weak exports flows seen between BRICS countries in Figure 4. On the contrary, the export flows of each BRICS country toward the G-7 group has intensified globally from 1995-1997 to 2010-2012. China has become a pivotal actor in the high-technology flows of the BRICS and G-7 network for the 2010-2012 period, a position that was held until then by the USA. On the opposite end, France's position in the network of exchanges has decreased, both in terms of flow intensity and proximity. The total value of exports made by the USA to BRICS and G-7 countries increased by $37.1 \%$ between the 1995-1997 and 2010-2012 period, the exports made by the UK increased about the same amount (37.6\% between 1995-1997 and 2010-2012) and Japan increased its exports of $41 \%$, again for the same period. The exports flows of BRICS countries show a quite different picture: India's exports to BRICS and G-7 countries increased 1066\% between 1995-1997 and 2010-2012, while the exports made by China increased 538\%, 167.2\% for exports made by South Africa, $151.1 \%$ for exports made by Russia and $131.8 \%$ for exports made by Brazil (see Appendix 2).

\footnotetext{
${ }^{7}$ includes 'Electronics (excluding parts and components) (SITC $751+752+761+762+763$ )', 'Parts and components for electrical and electronic goods (SITC $759+764+776)$ ', 'Machinery and transport equipment (SITC 7)', 'Medicinal and pharmaceutical products' (UNCTAD Statistics, 2014).
} 
The increasing proximity of BRICS countries to the G-7 cluster is explained by the improvement of the whole BRICS and G-7 cluster proximity. Indeed, Table 3 shows the increase in modularity value passing from 0.229 in $1995-1997$ period to 0.243 in 2010-2012 period. Simultaneously, the clustering index moved from 0.586 to 0.760 during the same period (Table 3 ).

Table 3. Modularity value and clustering index for BRICS and G-7 cluster

\begin{tabular}{ccc} 
Period & Modularity $^{*}$ & $\begin{array}{c}\text { Clustering } \\
\text { coefficient }^{* *}\end{array}$ \\
\hline $1995-1997$ & 0.229 & 0.586 \\
$2010-2012$ & 0.243 & 0.760
\end{tabular}

* using the Louvain Method for community detection which allows for detection and study of communities having closer 'distance' within the cluster. The algorithm generates 'modularity classes' which may be colored differently for network visualization and analysis (Blondel, Guillaume, Lambiotte and Lebfevre, 2008)).

** The clustering coefficient is the weighted value for every node in the cluster. It captures more precisely the effective level of cohesiveness and affinity due to the interaction strength between nodes (Latapy, 2008). 
India

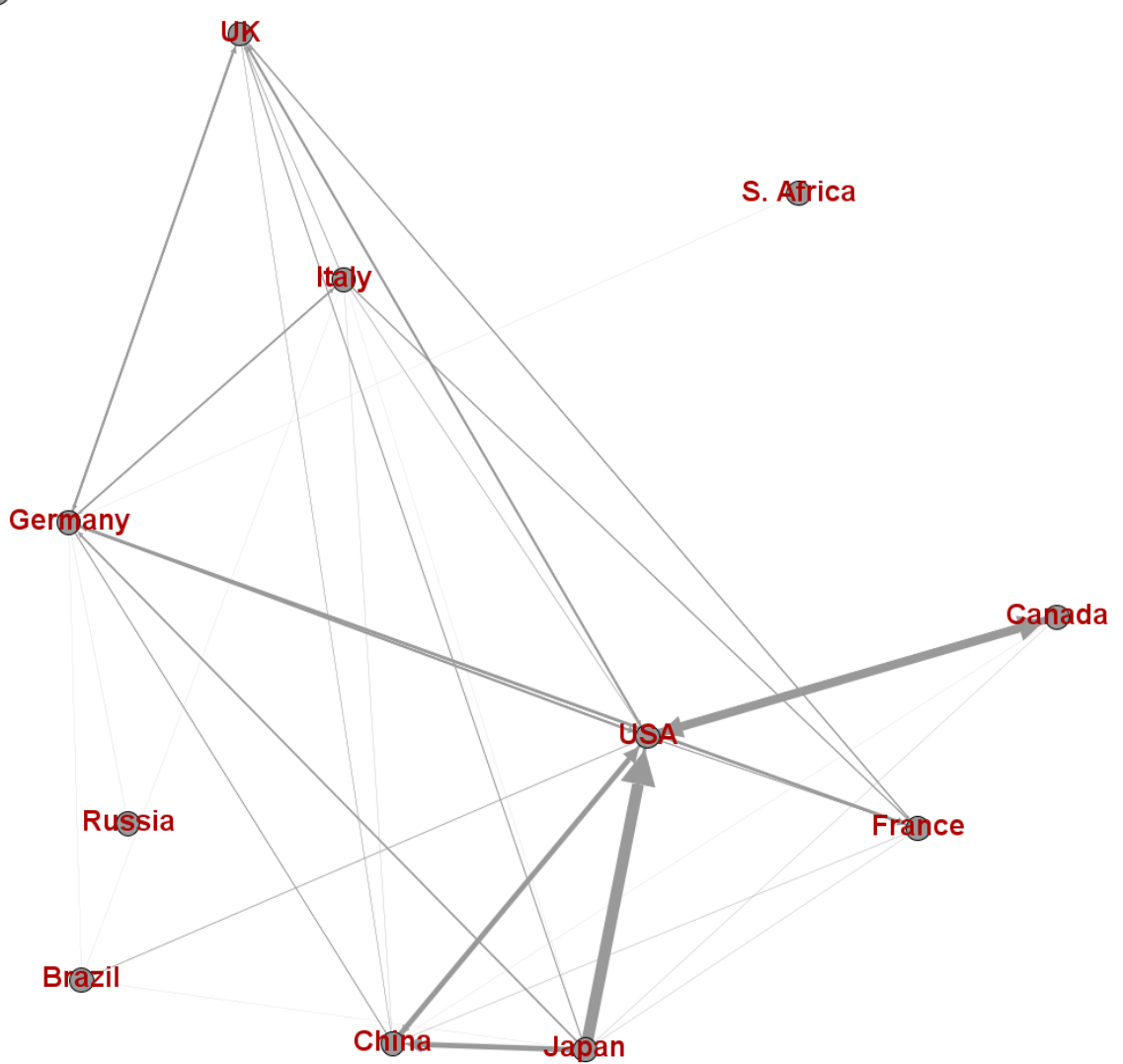

a) Period $1995-1997$

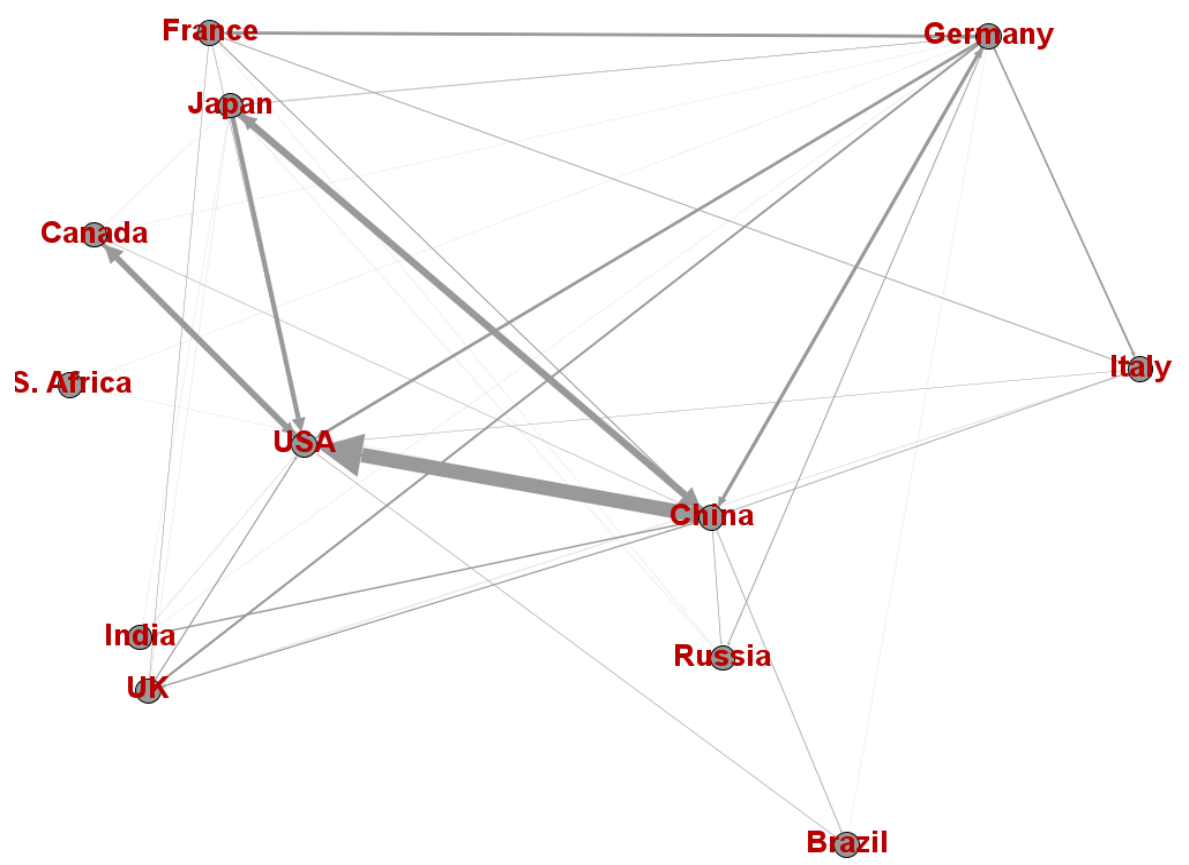

b) Period 2010-2012

Figure 4. High-technology import/export flows between G-7 and BRICS countries

The thickness of the link refers to the intensity of the exports and the distance between two entities refers to their respective proximity in the cluster 


\section{Conclusion}

Using Web of Science's scientific collaboration data and maps, this paper demonstrates that BRICS countries' increase in scientific production is to a large extent enhanced by BRICS' international collaboration, mainly with G-7 countries. For the 1995-1997 to 2010-2012 period, the USA remains at the center of the world's scientific production in almost all scientific fields while China is the fastest growing country both in terms of its scientific production and its collaboration proximity with G-7 countries. Maps of BRICS and G-7 collaboration clusters, based on the intensity of collaborations as well as on their proximity, provide evidence that Brazil, Russia, India and South Africa still remain at the periphery of the cluster even if their scientific output has significantly increased between 19951997 and 2010-2012. Furthermore, scientific collaboration amongst BRICS countries has not grown as fast as that between BRICS and G-7, suggesting that BRICS countries are individually collaborating with the G-7 countries that are still at the core of the scientific collaboration network with intensive intra-collaboration activities

While high-technology exports made by most BRICS countries to G-7 countries have increased between 1995-1997 and 2010-2012, the intra-BRICS high-technology exchanges as well as the intraBRICS scientific collaboration have remained very weak, which might be the result of several factors, namely: the competitiveness of BRICS countries among themselves, geographical distance (as the mean geographical distance of the BRICS group is almost twice the mean distance of the G-7 group), the lower purchasing power of some of these countries, and the lack of political will to fulfill the science cooperation agenda explicitly set during their first summit in 2009.

Our findings also suggest a relationship between high-technology economic activities of BRICS countries, the growth in their scientific production and their exogenous collaboration in intensive and technologically-related scientific activities. As BRICS countries increase their technological output and exchanges with G7 countries, scientific relationships between both groups of countries also increase which, in turn, positively affects the research infrastructure of BRICS countries and certainly leads to more scientific output. More research is necessary, however, to assess the extent of this relationship as well as the effects of collaborating with specific countries.

\section{References}

Abramo, G., D’Angelo, C. A., \& Solazzi, M. (2011). The relationship between scientists' research performance and the degree of internationalization of their research. Scientometrics, 86(3), 629643. doi:10.1007/s11192-010-0284-7

ARWU. (2014). Academic Ranking of World Universities 2014. Retrieved August $7^{\text {th }} 2015$ from http://www.shanghairanking.com/ARWU2014.html

Acosta M., Coronado D., Ferrándiz E., \& León, M.D. (2011). Factors affecting inter-regional academic scientific collaboration within Europe: the role of economic distance. Scientometrics, 87(1), 63-74. doi:10.1007/s11192-010-0305-6 
Basalla, G. (1967). The Spread of Western. Science, 156(3775), 611-622. doi:10.1126/science.156.3775.611

BBC (2009). Nations eye stable reserve system. Retrieved August $7^{\text {th }} 2015$ from http://news.bbc.co.uk/2/hi/business/8102216.stm

BCG Perspectives (2013). Allies and Adversaries: 2013 BCG Global Challengers. Retrieved August $7^{\text {th }} 2015$ from

https://www.bcgperspectives.com/content/articles/globalization_growth_allies_and_adversaries_2 013_bcg_global_challengers/

Beaver, D. de B. (2004). Does collaborative research have greater epistemic authority? Scientometrics, 60(3), 399-408. doi:10.1023/B:SCIE.0000034382.85360.cd

Blondel, V. D., Guillaume, J.-L., Lambiotte, R., \& Lefebvre, E. (2008). Fast unfolding of communities in large networks. Journal of Statistical Mechanics: Theory and Experiment, 2008(10), P10008. doi: 10.1088/1742-5468/2008/10/P10008

Bouabid, H., \& Larivière, V. (2013). The lengthening of papers' life expectancy: A diachronous analysis. Scientometrics, 97(3), 695-717. doi:10.1007/s11192-013-0995-7

Chan, L., \& Daim, T. (2012). Exploring the impact of technology foresight studies on innovation: Case of BRIC countries. Futures, 44(6), 618-630. doi:10.1016/j.futures.2012.03.002

Defazio, D., Lockett, A., \& Wright, M. (2009). Funding incentives, collaborative dynamics and scientific productivity: Evidence from the EU framework program. Research Policy, 38(2), 293305. doi:10.1016/j.respol.2008.11.008

Finardi, U. (2014). Scientific collaboration between BRICS countries. Scientometrics, 102(2), 11391166. doi:10.1007/s11192-014-1490-5

Finlay, S. C., Ni, C., \& Sugimoto, C. R. (2012). New methods for an old debate: Utilizing reader response to investigate the relationship between collaboration and quality in academic journal articles. Library \& Information Science Research, 34(2), 131-137. doi:10.1016/j.lisr.2011.11.003

Goswami, J. N., \& Annadurai, M. (2009). Chandrayaan-1: India's first planetary science mission to the moon. Current Science, 96(4), 486-491.

Graham, L. R. (1993). Science in Russia and the Soviet Union: A Short History. Cambridge University Press.

Grether J. M., \& Mathys N. A. (2010). Is the world's economic centre of gravity already in Asia? Area, 42(1), 47-50. doi: 10.1111/j.1475-4762.2009.00895.x

Hamers, L., Hemeryck, Y., Herweyers, G., Janssen, M., Keters, H., Rousseau, R., \& Vanhoutte, A. (1989). Similarity measures in scientometric research: The Jaccard index versus Salton's cosine formula. Information Processing \& Management, 25(3), 315-318. doi:10.1016/03064573(89)90048-4

Hanson, G. H. (2012). The Rise of Middle Kingdoms: Emerging Economies in Global Trade (Working Paper No. 17961). National Bureau of Economic Research. Retrieved August $7^{\text {th }} 2015$ from http://www.nber.org/papers/w17961

Harmer, A., \& Fleck, F. (2014). The BRICS countries: a new force in global health? Bulletin of the World Health Organization, 92(6), 394-395. doi:10.2471/BLT.14.030614 
Harzing, A.W., \& Giroud, A. (2014). The competitive advantage of nations: An application to academia. Journal of Informetrics, 8(1), 29-42. doi: 10.1016/j.joi.2013.10.007.

He, Z.-L., Geng, X.S., \& Campbell-Hunt, C. (2009). Research collaboration and research output: A longitudinal study of 65 biomedical scientists in a New Zealand university. Research Policy, 38(2), 306-317. doi:10.1016/j.respol.2008.11.011

Hoekman J., Frenken K., \& Tijssen R. J. W. (2010). Research collaboration at a distance: Changing spatial patterns of scientific collaboration within Europe. Research Policy, 39(5), 662-673. doi:10.1016/j.respol.2010.01.012

Institute of International Education. (2013). Top 25 Places of Origin of International Scholars, 2011/12-2012/13. Open Doors Report on International Educational Exchange. Retrieved August 7th 2015 from http://www.iie.org/opendoors

Jaccard, P. (1901). Distribution de la flore alpine dans le bassin de Dranses et dans quelques régions voisines. Bulletin de la Société Vaudoise des Sciences Naturelles, 37(140), 241-272. doi:10.5169/seals-266440

Katz, J. S., \& Hicks, D. (1997). How much is a collaboration worth? A calibrated bibliometric model. Scientometrics, 40(3), 541-554. doi:10.1007/BF02459299

Kharas, H.(2010). The emerging middle class in developing countries (Working Paper No. 285). OECD Development Centre. Retrieved August $7^{\text {th }} 2015$ from http://www.oecd.org/dev/44457738.pdf

King, D. A. (2004). The scientific impact of nations. Nature, 430(6997), 311-316. doi: $10.1038 / 430311 \mathrm{a}$

Klavans, R., \& Boyack, K. W. (2006). Identifying a better measure of relatedness for mapping science. Journal of the American Society for Information Science and Technology, 57(2), 251263. doi:10.1002/asi.20274

Klein, L. (2009). Measurement of a shift in the world's center of economic gravity. Journal of Policy Modelling, 31(4), 489-492. doi:10.1016/j.jpolmod.2009.05.005

Klein, L., \& Salvatore, D. (2013). Shift in the world economic center of gravity from G7 to G20. Journal of Policy Modelling, 35(3), 416-424. doi:10.1016/j.jpolmod.2013.03.004

Kock, C. J., \& Guillén, M. F. (2001). Strategy and Structure in Developing Countries: Business Groups as an Evolutionary Response to Opportunities for Unrelated Diversification. Industrial and Corporate Change, 10(1), 77-113. doi:10.1093/icc/10.1.77

Lakdawalla, E. (2014). China lands on the Moon. Nature Geoscience, 7(2), 81-81. doi:10.1038/ngeo2083

Larivière, V., Gingras, Y., \& Archambault, É. (2006). Canadian collaboration networks: A comparative analysis of the natural sciences, social sciences and the humanities. Scientometrics, 68(3), 519-533. doi:10.1007/s11192-006-0127-8

Larivière, V., Gingras, Y., Sugimoto, C. R., \& Tsou, A. (2015). Team size matters: Collaboration and scientific impact since 1900. Journal of the Association for Information Science and Technology, 66(7), 1323-1332. doi: 10.1002/asi.23266

Latapy, M. (2008). Main-memory triangle computations for very large (sparse (power-law)) graphs. Theoretical Computer Science, 407(1-3), 458-473. doi:10.1016/j.tcs.2008.07.017 
Lee, S., \& Bozeman, B. (2005). The Impact of Research Collaboration on Scientific Productivity. Social Studies of Science, 35(5), 673-702. doi:10.1177/0306312705052359

Levitt, J. M., \& Thelwall, M. (2010). Does the higher citation of collaborative research differ from region to region? A case study of Economics. Scientometrics, 85(1), 171-183. doi:10.1007/s11192-010-0197-5

Leydesdorff, L. (2008). On the normalization and visualization of author co-citation data: Salton's Cosine versus the Jaccard index. Journal of the American Society for Information Science and Technology, 59(1), 77-85. doi:10.1002/asi.20732

Leydesdorff, L., \& Zhou, P. (2005). Are the contributions of China and Korea upsetting the world system of science? Scientometrics, 63(3), 617-630. doi:10.1007/s11192-005-0231-1

Liao, S.H. (2005). Will China become a military space superpower? Space Policy, 21(3), 205-212. doi:10.1016/j.spacepol.2005.05.009

Mahmood, I. P., \& Zheng, W. (2009). Whether and how: Effects of international joint ventures on local innovation in an emerging economy. Research Policy, 38(9), 1489-1503. doi:10.1016/j.respol.2009.07.003

OECD. (2006). Science, Technology and Industry Outlook.

Retrieved August $7^{\text {th }} 2015$ from http://www.oecd.org/science/inno/oecdsciencetechnologyandindustryoutlook2006.htm

OECD (2010), Perspectives on global development 2010. Shifting Wealth.

Retrieved August $7^{\text {th }} 2015$ from http://www.oecd-ilibrary.org/development/perspectives-on-globaldevelopment-2010_9789264084728-en

OECD. (2012). Science, Technology and Industry Outlook.

Retrieved August $7^{\text {th }} 2015$ from http://www.oecd.org/sti/oecdsciencetechnologyandindustryoutlook.htm

OECD. (2013). How is international student mobility shaping up? Education Indicators in Focus (14), 4. doi: $10.1787 / 22267077$

Quah, D. (2011). The Global Economy’s Shifting Centre of Gravity. Global Policy, 2(1), 3-9. doi:10.1111/j.1758-5899.2010.00066.x

Rigby, J. (2009). Comparing the scientific quality achieved by funding instruments for single grant holders and for collaborative networks within a research system: Some observations. Scientometrics, 78(1), 145-164. doi:10.1007/s11192-007-1970-y

Scherngell T., \& Yuanjia, H. (2011). Collaborative Knowledge Production in China: Regional Evidence from a Gravity Model Approach. Regional Studies, 45(6), 755-772. doi:10.1080/00343401003713373

South Africa. (2011). New era as South Africa joins BRICS. Retrieved April 10 2015 from http://www.southafrica.info/global/brics/brics-080411.htm\#.VSkhdZOv-So

Stuenkel, O. (2013). The Financial Crisis, Contested Legitimacy, and the Genesis of Intra-BRICS Cooperation. Global Governance: A Review of Multilateralism and International Organizations, 19(4), 611-630. doi:10.5555/1075-2846-19.4.611

Sun, X., Kaur, J., Milojević, S., Flammini, A., \& Menczer, F. (2013). Social Dynamics of Science. Scientific Reports, 3, 1069. doi:10.1038/srep01069 
UNCTAD Statistics. (2015a). Nominal and real GDP, total and per capita, annual, 1970-2014. Retrieved August $7^{\text {th }} 2015$ from

http://unctadstat.unctad.org/wds/TableViewer/tableView.aspx ?ReportId=96

UNCTAD Statistics. (2015b). Real GDP growth rates, total and per capita, annual, 1970-2014. Retrieved August $7^{\text {th }} 2015$ from

http://unctadstat.unctad.org/wds/TableViewer/tableView.aspx?ReportId=109

UNCTAD Statistics. (2014). Merchandise trade matrix - detailed products, exports in thousands of dollars, annual, 1995-2013. Retrieved August $13^{\text {th }} 2014$ from http://unctadstat.unctad.org/wds/TableViewer/tableView.aspx?ReportId=24738

Yang, L. Y., Yue, T., Ding, J. L., \& Han, T. (2012). A comparison of disciplinary structure in science between the G7 and the BRIC countries by bibliometric methods. Scientometrics, 93(2), 497-516. doi:10.1007/s11192-012-0695-8

Wade, R. H. (2011). Emerging World Order? From Multipolarity to Multilateralism in the G20, the World Bank, and the IMF. Politics \& Society, 39(3), 347-378. doi:10.1177/0032329211415503 


\section{Appendix 1}

Engineering and Technology co-publications for the period 1995-1997

\begin{tabular}{|c|c|c|c|c|c|c|c|c|c|c|c|c|}
\hline & Brazil & Canada & China & France & Germany & India & Italy & Japan & Russia & S. Africa & UK & USA \\
\hline Brazil & & 49 & 11 & 71 & 45 & 7 & 30 & 16 & 18 & 0 & 72 & 165 \\
\hline Canada & & & 151 & 205 & 143 & 78 & 67 & 188 & 51 & 11 & 153 & 1031 \\
\hline China & & & & 57 & 166 & 3 & 59 & 270 & 10 & 2 & 231 & 461 \\
\hline France & & & & & 400 & 38 & 267 & 82 & 161 & 6 & 264 & 678 \\
\hline Germany & & & & & & 93 & 222 & 239 & 336 & 21 & 377 & 1018 \\
\hline India & & & & & & & 22 & 43 & 8 & 1 & 62 & 309 \\
\hline Italy & & & & & & & & 59 & 83 & 3 & 217 & 580 \\
\hline Japan & & & & & & & & & 114 & 2 & 175 & 1123 \\
\hline Russia & & & & & & & & & & 9 & 88 & 386 \\
\hline S. Africa & & & & & & & & & & & 35 & 46 \\
\hline UK & & & & & & & & & & & & 777 \\
\hline USA & & & & & & & & & & & & \\
\hline
\end{tabular}

Engineering and Technology co-publications for the period 2010-2012

\begin{tabular}{|c|c|c|c|c|c|c|c|c|c|c|c|c|}
\hline & Brazil & Canada & China & France & Germany & India & Italy & Japan & Russia & S. Africa & UK & USA \\
\hline Brazil & & 142 & 110 & 355 & 252 & 79 & 166 & 52 & 66 & 13 & 204 & 612 \\
\hline Canada & & & 1863 & 651 & 402 & 234 & 245 & 316 & 68 & 30 & 445 & 2473 \\
\hline China & & & & 1059 & 1216 & 215 & 288 & 2369 & 189 & 62 & 2848 & 8527 \\
\hline France & & & & & 1432 & 311 & 1142 & 454 & 407 & 92 & 1009 & 1808 \\
\hline Germany & & & & & & 411 & 949 & 538 & 587 & 65 & 1389 & 2455 \\
\hline India & & & & & & & 173 & 313 & 77 & 98 & 344 & 1296 \\
\hline Italy & & & & & & & & 221 & 189 & 25 & 943 & 1679 \\
\hline Japan & & & & & & & & & 148 & 15 & 501 & 1654 \\
\hline Russia & & & & & & & & & & 12 & 229 & 486 \\
\hline S. Africa & & & & & & & & & & & 109 & 161 \\
\hline UK & & & & & & & & & & & & 2178 \\
\hline USA & & & & & & & & & & & & \\
\hline
\end{tabular}


Medical Sciences co-publications for the period 1995-1997

\begin{tabular}{|c|c|c|c|c|c|c|c|c|c|c|c|c|}
\hline & Brazil & Canada & China & France & Germany & India & Italy & Japan & Russia & S. Africa & UK & USA \\
\hline Brazil & & 165 & 21 & 241 & 188 & 17 & 80 & 98 & 27 & 11 & 345 & 1118 \\
\hline Canada & & & 102 & 1182 & 777 & 54 & 433 & 626 & 99 & 57 & 1372 & 7570 \\
\hline China & & & & 134 & 132 & 22 & 47 & 413 & 25 & 4 & 206 & 824 \\
\hline France & & & & & 1871 & 85 & 1521 & 544 & 325 & 80 & 2480 & 4574 \\
\hline Germany & & & & & & 122 & 1314 & 845 & 542 & 114 & 2845 & 6792 \\
\hline India & & & & & & & 42 & 83 & 16 & 5 & 216 & 554 \\
\hline Italy & & & & & & & & 309 & 145 & 44 & 1868 & 4105 \\
\hline Japan & & & & & & & & & 119 & 35 & 1108 & 6425 \\
\hline Russia & & & & & & & & & & 6 & 336 & 905 \\
\hline S. Africa & & & & & & & & & & & 258 & 341 \\
\hline UK & & & & & & & & & & & & 7611 \\
\hline
\end{tabular}

Medical Sciences co-publications for the period 2010-2012

\begin{tabular}{|c|c|c|c|c|c|c|c|c|c|c|c|c|}
\hline & Brazil & Canada & China & France & Germany & India & Italy & Japan & Russia & S. Africa & UK & USA \\
\hline Brazil & & 1178 & 328 & 1169 & 1216 & 250 & 1059 & 387 & 116 & 207 & 1664 & 5821 \\
\hline Canada & & & 2553 & 3667 & 4032 & 608 & 2423 & 1419 & 266 & 460 & 6173 & 20856 \\
\hline China & & & & 1231 & 2204 & 466 & 789 & 3247 & 273 & 168 & 3280 & 20640 \\
\hline France & & & & & 6937 & 529 & 5561 & 1458 & 507 & 465 & 8152 & 11810 \\
\hline Germany & & & & & & 696 & 6722 & 2166 & 879 & 492 & 11779 & 19770 \\
\hline India & & & & & & & 393 & 534 & 82 & 187 & 1234 & 3656 \\
\hline Italy & & & & & & & & 1071 & 394 & 290 & 8011 & 12655 \\
\hline Japan & & & & & & & & & 222 & 133 & 2590 & 10986 \\
\hline Russia & & & & & & & & & & 63 & 617 & 1600 \\
\hline S. Africa & & & & & & & & & & & 1616 & 2408 \\
\hline UK & & & & & & & & & & & & 23715 \\
\hline
\end{tabular}


Earth and Space co-publications for the period 1995-1997

\begin{tabular}{|c|c|c|c|c|c|c|c|c|c|c|c|c|}
\hline & Brazil & Canada & China & France & Germany & India & Italy & Japan & Russia & S. Africa & UK & USA \\
\hline Brazil & & 41 & 9 & 136 & 63 & 14 & 67 & 27 & 19 & 17 & 88 & 240 \\
\hline Canada & & & 69 & 309 & 289 & 24 & 81 & 152 & 115 & 34 & 368 & 1557 \\
\hline China & & & & 82 & 114 & 7 & 23 & 99 & 27 & 7 & 94 & 276 \\
\hline France & & & & & 663 & 49 & 417 & 130 & 230 & 33 & 592 & 1412 \\
\hline Germany & & & & & & 81 & 433 & 149 & 319 & 68 & 703 & 1796 \\
\hline India & & & & & & & 30 & 42 & 20 & 9 & 68 & 198 \\
\hline Italy & & & & & & & & 51 & 104 & 18 & 353 & 696 \\
\hline Japan & & & & & & & & & 79 & 14 & 182 & 842 \\
\hline Russia & & & & & & & & & & 11 & 174 & 546 \\
\hline S. Africa & & & & & & & & & & & 93 & 154 \\
\hline UK & & & & & & & & & & & & 1983 \\
\hline USA & & & & & & & & & & & & \\
\hline
\end{tabular}

\section{Earth and Space co-publications for the period 2010-2012}

\begin{tabular}{|c|c|c|c|c|c|c|c|c|c|c|c|c|}
\hline & Brazil & Canada & China & France & Germany & India & Italy & Japan & Russia & S. Africa & UK & USA \\
\hline Brazil & & 140 & 76 & 402 & 377 & 50 & 202 & 83 & 47 & 49 & 300 & 756 \\
\hline Canada & & & 1010 & 1359 & 1486 & 162 & 736 & 482 & 205 & 202 & 1874 & 4425 \\
\hline China & & & & 666 & 1190 & 146 & 341 & 1001 & 183 & 71 & 1188 & 4768 \\
\hline France & & & & & 3258 & 290 & 2303 & 840 & 541 & 311 & 3104 & 5035 \\
\hline Germany & & & & & & 382 & 2463 & 1022 & 904 & 389 & 3757 & 6454 \\
\hline India & & & & & & & 152 & 271 & 100 & 79 & 287 & 889 \\
\hline Italy & & & & & & & & 546 & 339 & 170 & 2110 & 3364 \\
\hline Japan & & & & & & & & & 284 & 116 & 989 & 2596 \\
\hline Russia & & & & & & & & & & 61 & 487 & 966 \\
\hline S. Africa & & & & & & & & & & & 497 & 561 \\
\hline UK & & & & & & & & & & & & 6938 \\
\hline
\end{tabular}




\section{Appendix 2}

Total high-technology exports ${ }^{8}$ between BRICS and G-7 countries during the period 1995-1997

\begin{tabular}{|c|c|c|c|c|c|c|c|c|c|c|c|c|}
\hline $\begin{array}{l}\text { ECONOMY } \\
\text { PARTNER }\end{array}$ & Brazil & Canada & China & France & jermany & India & Italy & Japan & Russia & S. Africa & UK & USA \\
\hline Brazil & & 1108274.57 & 5535033.68 & 300504.26 & 9493056.27 & 57877.243 & 6585713.91 & 7008407.01 & 6609.451 & 89165.132 & 2165389.08 & 32114426.9 \\
\hline Canada & 221206.198 & & 83179 & 3141493.76 & 5864859.7 & 84703.051 & 26.02 & 16645337.5 & 33135.618 & 1046 & 48961.7 & 8834 \\
\hline China & .426 & 4768 & & 17403664 & 301 & 4945 & 24.6 & 7606 & 2035 & & 3.6 & 91.7 \\
\hline Frar & 3 & $165 t$ & 1112 & & 965 & 40 & 417 & 7.6 & & 49 & 9.8 & \\
\hline Germany & 1338 & 2702 & 3214 & 73327852.4 & & 6148 & 032 & 632 & 979 & 27 & 60 & 5.1 \\
\hline India & 466 & 2193 & 3158 & 1746650.03 & 5253 & & 196 & 3.2 & 26 & 28 & 27 & \\
\hline Italy & 1022789.75 & 601976.218 & 6795436.96 & 33278495.6 & 60869105.7 & 2453 & & 962 & 1090 & 26 & $22\}$ & 6.6 \\
\hline Japan & 235894.191 & 1442138 & 67426234.4 & 4190650.98 & 25910246.7 & 118273.571 & 3876 & & 151232.478 & 5325 & 13444269.3 & 54810 \\
\hline Russia & 32097.585 & 343591.131 & 1590619.85 & 2985800.86 & 12283325.4 & 408248.526 & 4250135.02 & 312 & & .987 & 3112746.8 & 4075608.28 \\
\hline S. & & & & 9.61 & 866 & & & 3.06 & & & 6052733.56 & \\
\hline UK & 562983.063 & 3561251.16 & 22280976.2 & 44363375 & 79249427.4 & 887791.014 & 23389342.1 & 43185341.6 & 153357.265 & 1584003.64 & & 76683916.1 \\
\hline USA & 9281469.95 & 241385697 & 172785615 & 31254443.7 & 84043622.3 & 1880985.5 & 22076804.4 & 374359641 & 320235.981 & 1709587.02 & 7684256.6 & \\
\hline
\end{tabular}

Total high-technology exports ${ }^{4}$ between BRICS and G-7 countries during the period 2010-2012

\begin{tabular}{|c|c|c|c|c|c|c|c|c|c|c|c|c|}
\hline $\begin{array}{l}\text { ECONOMY } \\
\text { PARTNER }\end{array}$ & Brazil & Canada & China & France & Germany & India & Italy & Japan & Russia & S. Africa & UK & USA \\
\hline Brazil & & 2537253.61 & 70666480.7 & 9810857.78 & 26691010.4 & 2087242.51 & 12426676.3 & 13317077 & 81423.658 & 319920.861 & 5886598.78 & 6124283 \\
\hline Canada & 991945.726 & & 53453342.7 & 4737524.96 & 21656047.8 & 901704.232 & 3849842.48 & 24466136.8 & 48197.372 & 504593.225 & 9620967.11 & 216 \\
\hline China & 3834264.87 & 7942057.86 & & 50376341.3 & 217196480 & 5427026.47 & 27123295.6 & 484992004 & 3507670.3 & 809485.138 & 43941631.1 & 214388418 \\
\hline France & 1522463.88 & 4522375.95 & 77749618.2 & & 226694799 & 2906982.87 & 65350976 & 16147164.2 & 341392.201 & 1251528.31 & 36676909.8 & 31109824.6 \\
\hline Germany & 5280281.74 & 4837382.23 & 213177059 & 151525172 & & 6008122.76 & 74013103.1 & 52969171 & 1772505.03 & 7137069.28 & 68851353.1 & 74715223 \\
\hline India & 763614.794 & 1478318.71 & 123846794 & 7370333.88 & 24517194.7 & & 8538856.34 & 17761377 & 4434286.8 & 317476.11 & 6256034.37 & 18408389 \\
\hline Italy & 1665948.74 & 1474353.96 & 70291088 & 44979299.7 & 124653569 & 3443127.97 & & 10540336.2 & 174977.18 & 240337.141 & 24604641.4 & 19444928.2 \\
\hline Japan & 559158.976 & 2258458.04 & 355441941 & 10144637.5 & 39220385.8 & 1300712.65 & 7181549.28 & & 799120.816 & 1427257.51 & 912.5 & 65888548.5 \\
\hline Russia & 3304 & 2295825.57 & 67461 & 1862 & 85292 & 3299508.86 & 15469563.2 & 2846 & & 333430.236 & 930 & 130 \\
\hline S. Africa & 1980408.99 & 843383.67 & 23301796.7 & 5132571.18 & 23208932.9 & 5415742.47 & 3438102.96 & 10234082.6 & 101001.027 & & 6651042.14 & 10384149.1 \\
\hline UK & 1616130.41 & 6583497.42 & 101301619 & 44510169.7 & 155854807 & 6045528.13 & 29828737.6 & 28851672.4 & 276240.857 & 2003242.72 & & 59348056.1 \\
\hline USA & 14485197.1 & 300398111 & 979671914 & 50710189.4 & 214285973 & 22380937.9 & 43565489.1 & 324882146 & 878554.417 & 7960331.9 & 85360632.4 & \\
\hline
\end{tabular}

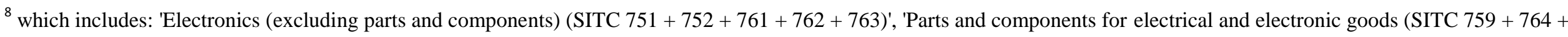
776)', 'Machinery and transport equipment (SITC 7)', 'Medicinal and pharmaceutical products'
} 
